\title{
A quarter century of oak woodland research in the Sierra foothills supports oak restoration
}

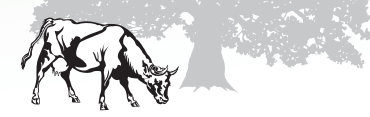

by Douglas D. McCreary

During the last 25 years, a wide variety of oak woodland research has been conducted at the UC Sierra Foothill Research and Extension Center. A substantial portion of this research has focused on developing procedures for artificially regenerating native California oaks. Results indicate that oaks can be successfully established with sufficient care and protection, including thorough weed control and protection from damaging animals. Tree shelters, or grow tubes, have proven particularly useful in getting seedlings to about 6.5 feet (2.0 meters), where they are relatively resistant to cattle browsing. These findings have been disseminated through training sessions and written materials and have been widely adopted by restoration practitioners, improving the overall success rate of oak plantings in California.

IN 1986, the University of California, in cooperation with the California Department of Forestry (now CalFire) and the California Department of Fish and Game, established the Integrated Hardwood Range Management Program (IHRMP) to address statewide concerns about oak woodland management and to promote woodland conservation (Passof 1987). This program funded five new Cooperative Extension specialists stationed throughout the state. In 1986, I was one of the new hires and was housed at the UC Sierra Foothill Research and Extension Center (SFREC) as a natural resources specialist for the northern Sierra region. This afforded an excellent opportunity to conduct oak woodland research in the foothills of the Sierra Nevada.

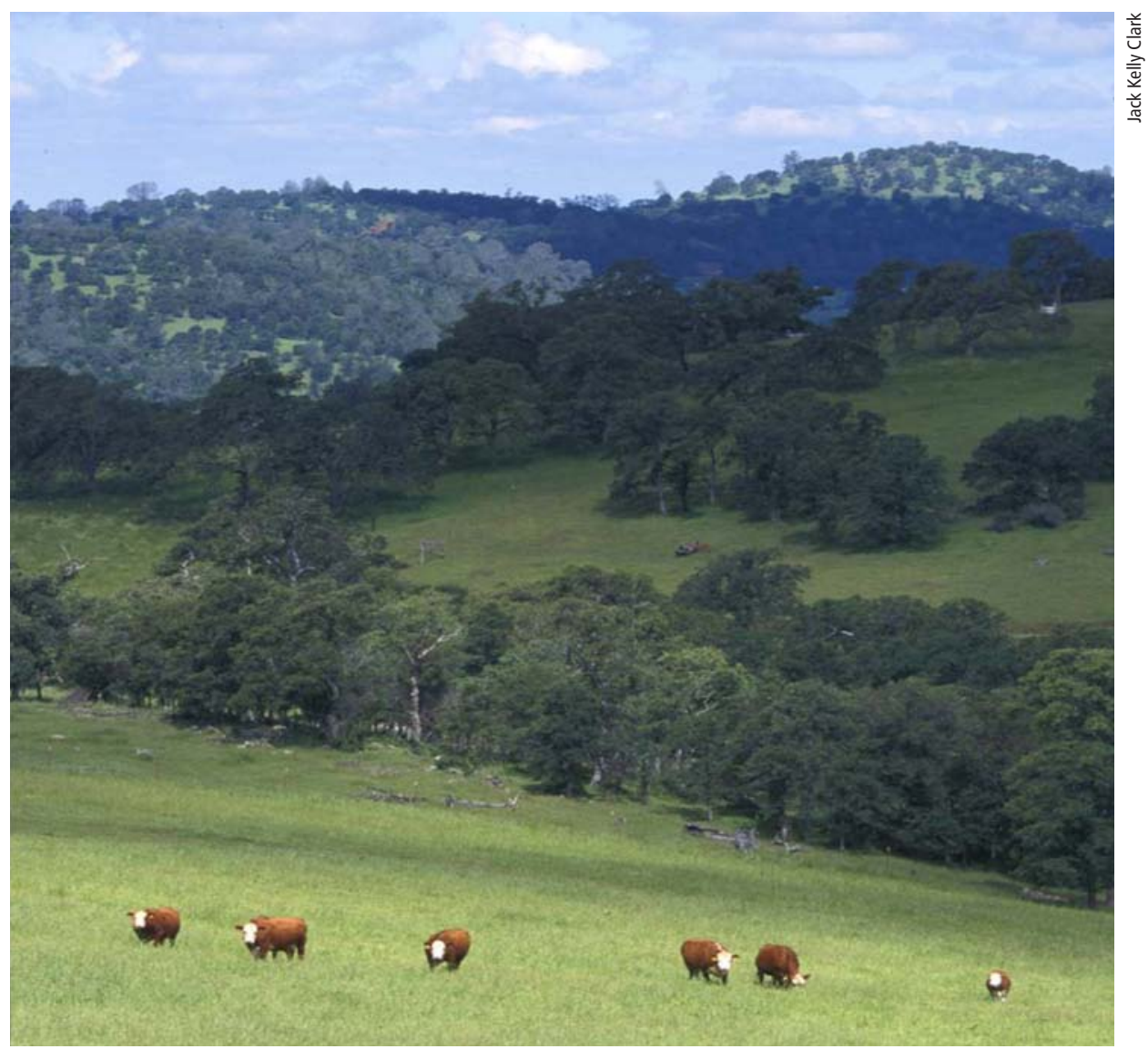

Cattle graze a typical oak woodland at the UC Sierra Foothill Research and Extension Center. Approximately $80 \%$ of the oak woodlands in California are privately owned and most are managed for livestock.

One of our main goals was to evaluate alternative oak-seedling production and planting techniques and develop practical methods for successfully regenerating native California oaks. The need for this research was based on one of the primary reasons cited for establishing the IHRMP: the widespread view that several species of California oaks, including blue oak (Quercus douglasii) and valley oak (Q. lobata), were not regenerating adequately. Poor natural regeneration raised the specter that some oak stands could convert to grasslands or shrublands. The concern was grave because woodlands provide critical habitat for a large and diverse assortment of wildlife; protect the quality of the state's water resources by anchoring the soil, preventing erosion and sedimentation; and provide beautiful scenery and opportunities for recreation (Bolsinger 1988).

\section{Early oak regeneration research}

Even before the IHRMP was founded there had been several projects at SFREC to examine natural oak regeneration patterns. In the mid-1960s, Burgess L. (Bud) Kay, a UC Davis range science specialist, established plots to evaluate the effects of blue oak removal on a variety a factors, including oak regeneration (Kay 1987). He found that about half of the untreated stumps sprouted following the experimental harvest, but that no new blue oak seedlings actually established in the plot area during the 23 years since harvesting.

In the early 1980s, UC Berkeley range student Mitch McClaran conducted his Ph.D. dissertation research at SFREC on 
the age structure of blue oak in relation to livestock grazing and fire (McClaran 1986). This research contributed to a better understanding of oak reproduction patterns. McClaran found that oaks had established at SFREC irregularly but continuously over a very long time interval and that pulses of apparent regeneration were associated with the occurrence of fire. This was because fires often killed the aboveground portion of the plant, and these damaged trees became re-established by sprouting from their bases.

Several years after McClaran initiated his research, the late Theodore (Ted) Adams Jr., a Cooperative

Extension rangeland specialist at UC Davis, began trials to evaluate the effects of seedling protection and weed control on oak establishment (Adams et al. 1987). At that time, little was known about oak seedling physiology or planting methods, so some of these early trials resulted in high mortality. But the results were still useful for subsequent research because they identified some of the critical obstacles.

Immediately after the program began, IHRMP funded competitive grants to address critical hardwood issues. The first round of funding in 1986 supported a large research project by UC Davis range scientists Kevin Rice, John Menke and Jeff Welker on the ecology and regeneration of hardwood

\section{Since most of the hardwood rangelands in California are privately owned, it is important to develop oak regeneration procedures that allow livestock operators to continue grazing their woodlands.}

rangelands, and the role of grazing and introduced Mediterranean annuals on oak seedling establishment. This research was undertaken at SFREC and two other field sites. It showed that livestock grazing had both direct and indirect effects on oak regeneration. Cattle adversely affected oak seedlings directly via browsing, but grazing also indirectly limited recruitment by reducing organic matter and compacting the soil (Welker and Menke 1987). This and subsequent research also suggested that the widespread introduction of Mediterranean annuals throughout the state since European settlement probably also adversely affected natural oak regeneration by changing soil-water relations (Gordon and Rice 1993). A study several years later found that SFREC, like numerous other woodland sites throughout the state, had a paucity of blue oak saplings (Swiecki et al. 1997), implying that the bottleneck to successful tree replacement was from the seedling to the sapling stage.

\section{Oak woodland ecology studied}

In addition to research on oak regeneration, other studies at SFREC in the

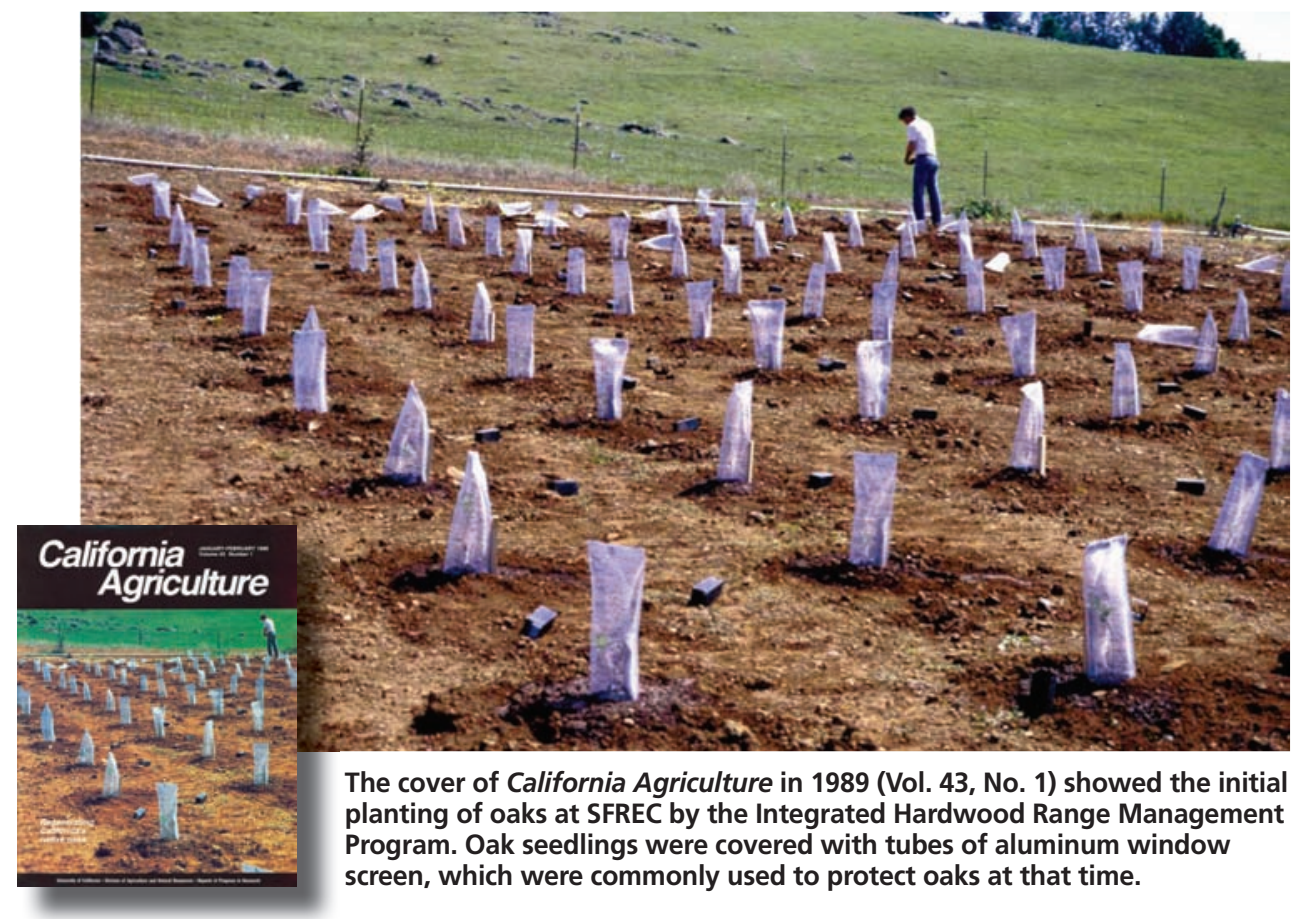

late 1980s and early 1990s addressed various aspects of oak woodland ecology. A study in the Schubert watershed reported that partial tree harvesting had relatively little impact on water quality and yield (Singer et al. 1990). Major storm events, such as the warm spring storm in early 1986, contributed far more sediment to streams than any oak removal. Other studies evaluated nutrient relations and the chemical composition of woodland soils. Researchers found increased rates of nutrient cycling under trees (compared to open pastures) and reported that oak woodlands retained more nutrients than cleared areas (Jackson et al. 1990; Dahlgren and Singer 1991) (see page 78).

There were also studies on the relationship between woodland characteristics and wildlife use. One determined that removing approximately $23 \%$ of the basal area (the sum of the crosssectional area of all trees measured at breast height, 4.5 feet or 1.37 meters above the ground) in 7.7-acre plots (3.1 hectares) did not significantly affect the abundance or use of woodlands by most bird species (Aigner et al. 1997). Another reported that the wide diversity of habitats found at SFREC supported a wide range of wildlife and that no habitat types were unused (Block and Morrison 1990). This study reaffirmed the idea that woodland wildlife benefit from both vertical and horizontal structural plant diversity and that widespread tree removal can adversely affect populations of a range of wildlife species.

In the last 10 to 15 years, other questions about oak woodland ecology and management have been addressed. A group from UC Davis - including Caroline Bledsoe and co-investigators Robert Zasoski, William Horwath, David Rizzo and their students focused on the belowground control of nitrogen uptake by ectomycorrhizal oak and pine roots. (Mycorrhiza refers to the symbiotic association between higher plant roots [hosts] and specific fungi that aid plants in the uptake of water and nutrients and may offer protection against 


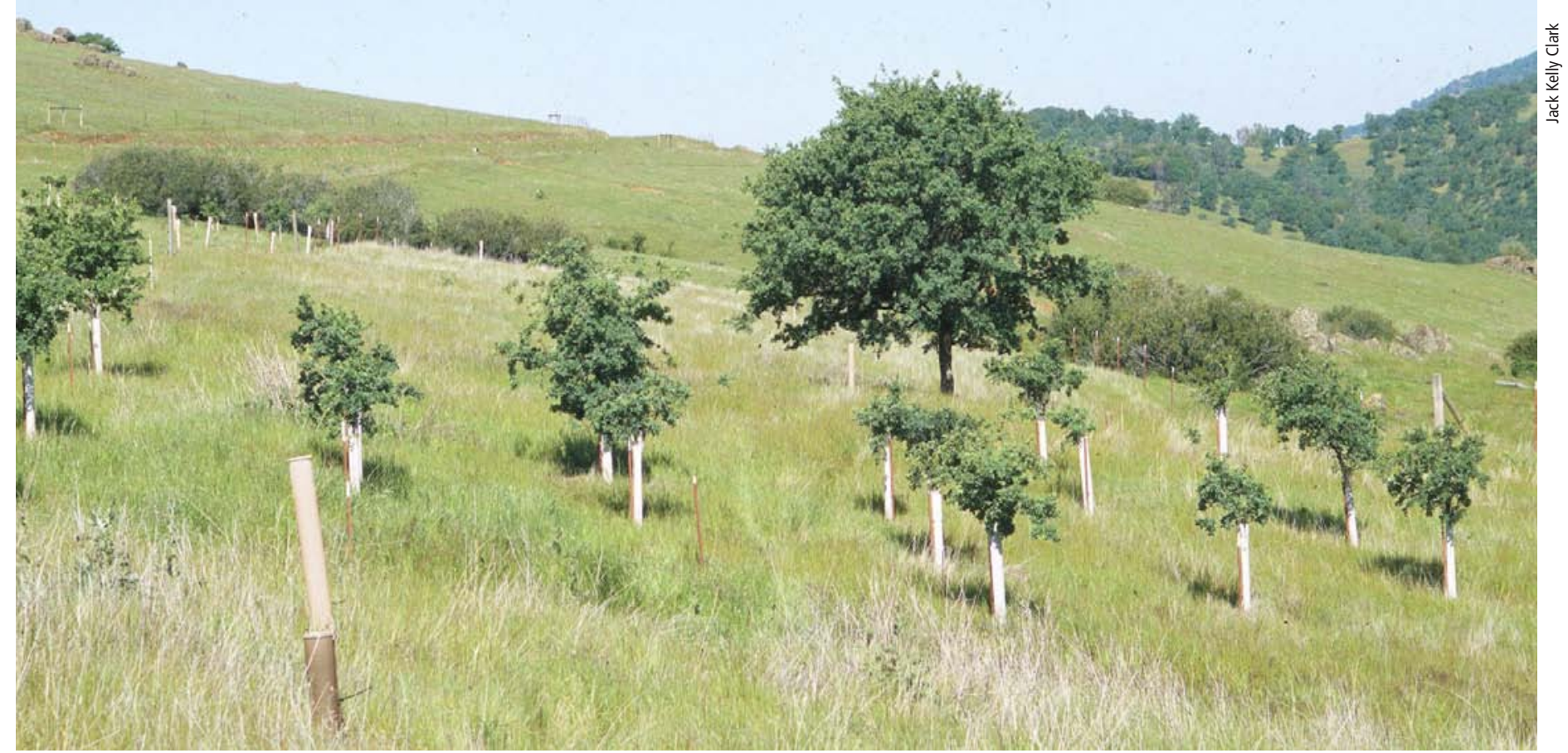

Tree shelters helped to get blue oak seedlings established and growing rapidly in an oak regeneration plot at SFREC.

soilborne organisms.) They discovered that oaks and pines have a diverse fungal community on their roots that aids in nutrient uptake. Mycorrhizae also play a critical role in oak establishment (Berman and Bledsoe 1998), water uptake (Millikin and Bledsoe 1999) and nitrogen capture (Cheng and Bledsoe 2004).

Kevin Rice and students from UC Davis have looked at blue oak pollen distribution and discovered that isolated blue oaks may have a limited ability to exchange pollen with relatively distant neighbors, suggesting that the continuing fragmentation of woodlands could have serious and adverse impacts on genetic diversity within this species (Knapp et al. 2001). And Barbara AllenDiaz and students from UC Berkeley evaluated springs within oak woodlands and found that moderate grazing in these systems had relatively little impact on soil chemistry, water quality or invertebrate populations (Allen-Diaz et al. 2004).

\section{Artificial regeneration of oaks}

The first research project initiated at SFREC by the IHRMP was a planting in 1987 to determine how to successfully grow and establish blue oaks. One hundred and twenty 1-year-old seedlings were planted and given thorough weed control, protection from potentially damaging animals and initial irrigation to ensure adequate moisture. In this rather pampered environment almost all the seedlings survived, providing a bank of young plants for subsequent studies (McCreary 1989). This study provided a baseline for determining which factors were most critical to oak establishment. Subsequent research indicated that weed control and animal protection were usually essential, but that irrigation was often not necessary (at least at SFREC), as long as competing weeds were controlled. Three years later, the seedlings in this initial planting were part of a study that evaluated seasonal growth patterns of blue oak and valley oak (McCreary 1991).

During the next 10 years additional studies were initiated that examined different aspects of oak regeneration, including when to collect and how to store acorns (McCreary and Koukoura 1990), when to directly sow acorns in the field (McCreary 1990), the effects of acorn size on seedling morphology and field performance (Tecklin and McCreary 1991), the effects of toppruning young seedlings prior to field planting (McCreary and Tecklin 1993), lifting (removal from the ground) and storage intervals for seedlings produced in bare-root nurseries (McCreary and Tecklin 1994), the effects of augering and fertilization on field growth and survival (McCreary 1995) and the effects of radicle (initial seedling root) pruning on seedling performance (McCreary 1996).

In brief, these studies demonstrated the following:

- Healthy blue oak acorns can be collected over a 6-week interval in the fall, but allowing acorns to dry out can be lethal to subsequent germination.

- Large acorns initially produce larger seedlings than small acorns.

- The early sowing of acorns results in early germination and root growth, resulting in better field performance.

- Top-pruning tall and lanky container seedlings can help them become established after field planting.

- Bare-root blue oak seedlings can be stored for up to 2 months after lifting, but it is important to plant seedlings by early January.

- Augering and fertilization both stimulate more rapid initial field growth of seedlings.

- Radicle pruning prior to planting has relatively little impact on subsequent seedling growth.

All of these findings, as well as results from other regeneration-related research in California, were summarized 


\section{Healthy cattle, healthy oaks}

Prior to the mid-1970s, oaks in California were often considered undesirable weeds that prevented other, more productive uses of the land. This led to federal cost-share programs to remove oaks and other woody vegetation from foothill properties so that forage production for livestock could be enhanced. Between 1945 and 1973, approximately 1.9 million acres of hardwoods and chaparral were cleared for "rangeland improvement" projects (Bolsinger 1988).

Oak woodlands were further affected in the early 1980s when whole sections (640 acres) of rangelands, especially in the northern Sacramento Valley, were clear-cut for firewood. Both of these practices have now been largely discredited and discontinued. Today, oak removal that does take place for firewood harvesting is much more likely to be a thinning, where numerous trees are retained. Research by Rick Standiford, UC Cooperative Extension forestry specialist at UC Berkeley, and others at SFREC and elsewhere has helped to identify growth rates on which to base harvesting levels, so that stands can be managed more sustainably (Standiford 1997; Standiford et. al 1996).

Oak regeneration in California is much more successful today because of research at SFREC. It is now well recognized that eliminating competing vegetation near seedlings and protecting young oaks from damaging animals are essential. Tree shelters are now widely used, and it is common practice to leave them in place for several years after the seedlings have emerged through the tops. Popular and scientific publications promoting weed control and animal protection - based on SFREC research - have been widely distributed, and this information has also been presented at SFREC oak regeneration field days as well as scores of workshops and symposia.

Cattle ranchers own a majority of oak woodlands in the state, and in general they are good stewards of their land and want to maintain or enhance their oak resources. Research at SFREC has provided guidance for how to do this. Studies have indicated the best times to graze woodlands so that young oak seedlings are less likely to be damaged. Research has also identified the general size that oaks need to be to withstand animal impacts. Such information helps landowners manage their oaks and livestock together without the need to remove land from production. in a 2001 publication designed to help practitioners successfully regenerate rangeland oaks (McCreary 2001). The research results were also presented at semiannual oak regeneration field days at SFREC targeted to restoration professionals.

\section{Protecting seedlings from animals}

The studies were established within large fenced areas that prevented damage from livestock, deer and other browsers. This made these studies easier to conduct but it did not mimic natural conditions, where both natural and planted oaks face a plethora of animals intent on eating them. A series of studies aimed at evaluating alternative methods for protecting young oaks from animal damage was therefore initiated. This research soon began to focus on using tree shelters, or grow tubes, to protect seedlings, since they seemed more effective than other devices previously used such as cylinders of aluminum window screen or plastic mesh.

Tree shelters are generally solid, double-walled plastic tubes that are placed over individual seedlings. Several manufacturers make such shelters, including Treessentials, Tree-Pro, Blue- $X$ and Plantra. Their products vary in the type and thickness of the plastic used and in physical design and construction. Some are rigid and come nested, while others are flat and assembled on site. They not only protect seedlings from a wide range of animals including livestock, deer, rabbits, voles and grasshoppers, but also alter the environment and stimulate rapid height growth (McCreary 1997). This growth promotion results from changes in the microenvironment inside the shelter, including reduced wind and transpiration, and increased temperature, humidity and carbon dioxide concentration (Potter 1991).

Studies were also initiated to determine the most effective shelter size and the influence of shelters on shoot height and diameter growth (McCreary and Tecklin 2001). The latter study demonstrated that the length of time tree shelters are left in place can be critical. Seedlings in tree shelters initially have rapid height growth, but this usually occurs at the expense of diameter growth, which causes the seedlings to grow very tall and spindly. If the shelters are removed before the seedlings grow to the tops of the tubes, the seedlings often cannot support themselves and will fall over unless they are staked. However, research demonstrated that once seedlings reach the tops of the shelters, height growth diminishes and diameter growth accelerates. After 2 or 3 years growing above the shelters, the seedlings develop sufficient girth to remain upright, even after the shelters are removed. Based on these findings, leaving shelters in place for at least 2 years after the seedlings grow to the shelter top is recommended.

Another study evaluated how seedlings respond when shelters are added several years after the initial planting. In this "retrofitting" experiment, shelters were placed over seedlings that had been planted 2 years earlier, but had languished with little growth. Almost immediately after having the shelters placed over them, the seedlings began to grow rapidly; 2 years later, average seedling height was nearly 4 feet (1.3 meters). By comparison, nonretrofitted control seedlings grew very little and remained less than a foot ( 0.3 meter) tall (Tecklin et al. 1997).

One significant advantage of tree shelters is that in lightly to moderately grazed pastures, they can also protect seedlings from livestock. Since most of the hardwood rangelands in California are privately owned and livestock grazing is the primary management activity, it is important to develop oak regeneration procedures that allow livestock operators to continue grazing their woodlands. Research has indicated that in some situations tree shelters can successfully protect seedlings from livestock damage without the need for fences and animal exclusion (McCreary 1999).

Tree shelters are widely used by CalTrans and by the vineyard industry for establishing vines, and are also used in various mitigation projects with oaks and other tree species. They are occasionally used by private landowners, including ranchers, but generally on a small scale. However, tree shelters are not inexpensive. The current price for 4 -foot ( 0.3 meter) Treessentials shelters is more than $\$ 4$ 


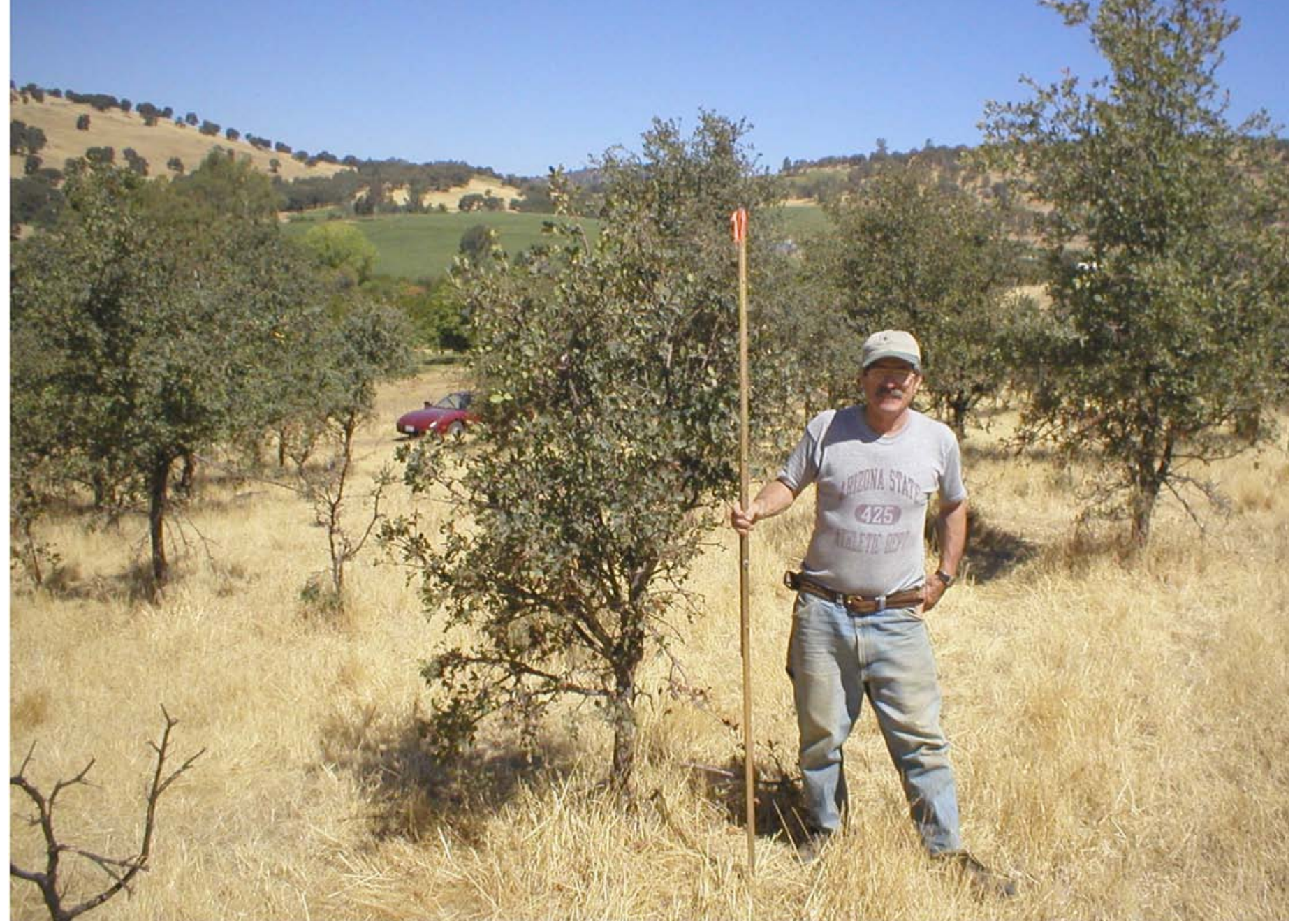

Decades of research at SFREC have helped to establish guidelines for regenerating oaks in grazed woodlands. Staff research associate Jerry Tecklin demonstrates that blue oaks more than 6.5 feet ( 2 meters) tall are relatively resistant to cattle impacts, while seedlings shorter than 6.5 feet are adversely affected.

each, so using them over large areas would likely be prohibitively expensive for most private landowners. Costshare programs (that help subsidize the cost of purchasing and installing tree shelters) to encourage hardwood restoration are common in Great Britain and other parts of Europe, but are generally not available in California (McCreary and Kerr 2002).

Another important question related to artificially establishing oaks in areas grazed by livestock is the size that seedlings, or in this case, saplings, have to be before they are relatively resistant to livestock impacts. A recent study at SFREC evaluated cattle impacts on blue oak seedlings and saplings ranging in height from a foot ( 0.3 meter) to more than 10 feet ( 3 meters). These seedlings were left over from an integrated pest management (IPM) research project that Ted Adams had established at SFREC in the early 1990s. The results indicated that once seedlings attain a height of about 6.5 feet (2 meters), they are relatively resistant to live- stock damage and continue to grow and prosper. If they are less than this height when they are exposed to grazing, however, they continue to be severely affected by cattle, with minimal growth and high mortality (McCreary and George 2005).

\section{Evaluating natural regeneration}

Recently, a study evaluating another approach to oak regeneration was initiated at SFREC. This study, replicated at five other sites throughout California, examines the use of natural or "volunteer" blue oak seedlings as part of a strategy to enhance oak regeneration. The UC Agriculture and Natural Resources Core Grants Program funded a 2006 proposal, "Evaluating Techniques to Enhance Natural Blue Oak Regeneration." The project is evaluating several treatments, including weed control and tree shelters, to determine if taking steps to enhance the growth and survival of natural seedlings can get them to the sapling stage where they are less vulnerable to damaging factors. Preliminary results suggest that tree shelters can greatly aid in this effort.

\section{Long-term woodland conservation}

The research-based information generated from studies at SFREC has been extremely important in developing management recommendations consistent with long-term woodland conservation. This review has focused on oak regeneration research where SFREC has led the way in producing practical guidelines for those interested in restoring California's oak woodlands. But SFREC has also been the site of woodland research on a wide range of other subjects including wildlife, hydrology, fire, edaphic (soil community) characteristics and range management. This research has been instrumental in developing practical management guidelines for woodland owners and managers (see sidebar). While UC oak researchers have answered many fundamental questions about regeneration and range management in the last 25 


\section{References}

Adams TE, Sands PB, Weitkamp WH, et al. 1987 Enemies of white oak regeneration. In: Plumb TR, Pillsbury NH (tech. coords.). Proc Symp Multiple-use Management of California's Hardwood Resources. US Department of Agriculture, Forest Service Gen Tech Rep PSW-100. p 459-62.

Aigner PA, Block WM, Morrison ML. 1997. Effect of firewood harvesting on birds in a California oak-pine woodland. J Wildlife Manage 62(2):485-96.

Allen-Diaz B, Jackson R, Bartolome J, et al. 2004 Long-term grazing study in spring-fed wetlands reveals management tradeoffs. Cal Ag 58:144-8.

Berman JT, Bledsoe CS. 1998. Soil transfers from valley oak (Quercus lobata Nee) stands increase ectomycorrhizal diversity and alter root and shoot growth on valley oak seedlings. Mycorrhiza 7:223-35.

Block WM, Morrison ML. 1990. Wildlife diversity of the central Sierra foothills. Cal Ag 44(2):19-22

Bolsinger CL. 1988. The Hardwoods of California's Timberlands, Woodlands and Savannas. US Department of Agriculture, Forest Service Pacific Northwest Research Station, Res Bull PNW-148. 148 p.

Cheng XM, Bledsoe CS. 2004. Competition for inorganic and organic $\mathrm{N}$ by blue oak (Quercus douglasii) seedlings, an annual grass, and soil microorganisms in a pot study. Soil Bio Biochem 36:135-44.

Dahlgren R, Singer MJ. 1991. Nutrient cycling in managed and unmanaged oak woodland-grass ecosystems. In: Standiford RB (tech. coord.). Proc Symp on Oak Woodlands and Hardwoods Rangeland Mgmt. US Department of Agriculture, Forest Service Gen Tech Rep PSW-126. p 337-41.

Gordon DR, Rice KJ. 1993. Competitive effects of grassland annuals on soil water and blue oak (Quercus douglasii) seedlings. Ecology 74(1):68-82.

Jackson LE, Strauss RB, Firestone MK, Bartolome JW. 1990. Influence of tree canopies on grassland productivity and nitrogen dynamics in deciduous oak savanna. Ag Ecosys Env 32:89-105.

Kay BL. 1987. Long-term effects of blue oak remova on forage production, forage quality, soil, and oak regeneration. In: Plumb TR, Pillsbury NH (tech. coords.) Proc Symp Multiple-use Management of California's Hardwood Resources. US Department of Agriculture Forest Service Gen Tech Rep PSW-100. p 351-7.

Knapp EE, Goedde MA, Rice KJ. 2001. Pollen-limited reproduction in blue oak: Implications for wind pollination in fragmented populations. Oecologia 128:48-55.
McClaran MP. 1986. Age structure of Quercus douglasii in relation to livestock grazing and fire. Ph.D. thesis, UC Berkeley. $119 \mathrm{p}$

McCreary DD. 1989. Regenerating native oaks in California. Cal Ag 43(1):4-6.

McCreary DD. 1990. Acorn sowing date affects field performance of blue and valley oaks. Tree Planters Notes $41(2): 6-9$

McCreary DD. 1991. Seasonal growth patterns of blue and valley oaks established on foothill rangelands. In: Standiford RB (tech. coord.). Proc Symp on Oak Woodlands and Hardwoods Rangeland Mgmt. US Departmen of Agriculture, Forest Service Gen Tech Rep PSW-126. p $36-40$.

McCreary DD. 1995. Augering and fertilization stimulate growth of blue oak seedlings planed from acorns, but not from containers. West J Appl For 10(4):133-7.

McCreary DD. 1996. The effects of stock type and radicle pruning on blue oak morphology and field performance on oak morphology. Annales Sciences Forestieres 53(2-3):641-8

McCreary DD. 1997. Tree shelters: An alternative for oak regeneration. Fremontia 25(1):26-30

McCreary DD. 1999. Restoration of a grazed riparian area. In: Rose RR, Haase DL (coords., eds.). Proc Symp, Native Plants: Propagating and Planting. Dec 9-10, 1998, Corvallis, OR. p 86-91.

McCreary DD. 2001. Regenerating Rangeland Oaks in California. UC ANR Pub 21601. 62 p.

McCreary DD, George M. 2005. Managed grazing and seedling shelters enhance oak regeneration on rangelands. Cal Ag 59(4):217-22.

McCreary DD, Kerr G. 2002. A comparison of the history and management of oak woodlands in Britain and California. In: Standiford RB, McCreary DD, Purcell KL (tech. coords.). Proc Fifth Oak Symposium: Oaks in California's Changing Landscape. Oct. 22-25, 2001, San Diego, CA. US Department of Agriculture, Forest Service Pacific Southwest Research Station, Gen Tech Rep. PSW GTR-184. p 529-39.

McCreary DD, Koukoura Z. 1990. The effects of collection date and pre-storage treatment of the germination of blue oak acorns. New Forests 3:303-10.

McCreary DD, Tecklin J. 1993. Top pruning improves field performance of blue oak seedlings. Tree Planters Notes 44(2):73-7.

McCreary DD, Tecklin J. 1994. Lifting and storing bareroot blue oak seedlings. New Forests 8:89-103.
McCreary DD, Tecklin J. 2001. The effects of different-sized tree shelters on blue oak growth. West J Appl For 16(4):153-8

Millikin CS, Bledsoe CS. 1999. Biomass and distribution of fine and coarse roots from blue oak (Quercus douglasii) trees in the northern Sierra Nevada foothills of California. Plant Soil 214:27-38.

Passof PC. 1987. Developing an educational program to address the management of California's hardwood rangelands. In: Plumb TR, Pillsbury NH (tech. coords.). Proc Symp Multiple-use Management of California's Hardwood Resources. US Department of Agriculture, Forest Service Gen Tech Rep PSW-100. p 394-9.

Potter MJ. 1991. Treeshelters. Forestry Commission Handbook 7. London: HMSO Pub Cent. 48 p.

Singer MJ, Huang X, Epifanio C. 1990. Selective oak removal does not harm water quality. Cal Ag $44(2): 17-8$

Standiford RB. 1997. Growth of blue oak on California's hardwood rangelands. In: Pillsbury NH, Verner J, Tietje WD (tech. coords.). Proc Symp Oak Woodlands: Ecology, Management, and Urban Interface Issues. US Department of Agriculture, Forest Service Gen Tech Rep PSW-GTR-160. p 169-76.

Standiford RB, McCreary DD, Barry S, et al. 1996. Impact of firewood harvesting on hardwood rangelands varies with region. Cal $\mathrm{Ag} \mathrm{50(2):7-12.}$

Swiecki TJ, Bernhardt EA, Drake C. 1997. Stand leve status of blue oak sapling recruitment and regeneration. In: Pillsbury NH, Verner J, Tietje WD (tech. coords.). Proc Symp Oak Woodlands: Ecology, Management, and Urban Interface Issues. US Department of Agriculture, Forest Service Gen Tech Rep PSWGTR-160. p 147-56.

Tecklin J, Connor JM, McCreary DD. 1997. Rehabilitation of a blue oak restoration project. In: Pillsbury NH, Verner J, Tietje WD (tech. coords.). Proc Symp Oak Woodlands: Ecology, Management, and Urban Interface Issues. US Department of Agriculture, Forest Service Gen Tech Rep PSW-GTR-160. p 267-73.

Tecklin J, McCreary DD. 1991. Acorn size as a factor in early seedling growth of blue oaks. In: Standiford RB (tech. coord.). Proc Symp Oak Woodlands and Hardwoods Rangeland Mgmt. US Department of Agriculture, Forest Service Gen Tech Rep PSW-126. p 48-53.

Welker JM, Menke JM. 1987. Quercus douglasii seedling water relations in mesic and grazing-induced xeric environments. In: Proc Int Conf on Measurements of Soil and Plant Water Status, Vol. 2, Plants, July 6-10, 1987, Logan, UT. Utah State Univ. p 229-34. years, there is still much to be discovered and understood about woodland ecology and conservation. We still cannot explain why oaks naturally regenerate on some sites but not on others, and more research is needed to fully understand how to regenerate whole plant communities rather than single species. SFREC will likely continue to play a critical role in addressing these questions as well as others, and in disseminating answers to the public.

\section{D.D. McCreary is UC Cooperative Extension} Natural Resources Specialist, Department of Environmental Science, Policy and Management, UC Berkeley. He is stationed at SFREC, and is grate- ful to the UC Division of Agriculture and Natural Resources (ANR) for financial support through an ANR Core Grant that funded the installation and early measurements for the natural oak regeneration study; Jerry Tecklin, Staff Research Associate at SFREC for many years, who did much of the field work on the projects described; and the management and staff at SFREC who provided invaluable help and support throughout the past two decades. 